\title{
Statistical investigation of Kluyveromyces lactis cells permeabilization with ethanol by response surface methodology
}

\author{
Janaína T. de Faria ${ }^{1}$, Pollyana F. Rocha ${ }^{2}$, Attilio Converti ${ }^{3}$, Flávia M.L. Passos ${ }^{4}$, \\ Luis A. Minim ${ }^{1}$, Fábio C. Sampaio ${ }^{2}$ \\ ${ }^{1}$ Departamento de Tecnologia de Alimentos, Universidade Federal de Viçosa, Viçosa, MG, Brazil. \\ ${ }^{2}$ Departamento de Farmácia, Universidade Federal dos Vales do Jequitinhonha e Mucuri, \\ Diamantina, MG, Brazil. \\ ${ }^{3}$ Department of Civil, Chemical and Environmental Engineering, University of Genoa, Genoa, Italy. \\ ${ }^{4}$ Departamento de Microbiologia, Universidade Federal de Viçosa, Viçosa, MG, Brazil.
}

Submitt: October 02, 2011; Approved: April 4, 2013.

\begin{abstract}
The aim of our study was to select the optimal operating conditions to permeabilize Kluyveromyces lactis cells using ethanol as a solvent as an alternative to cell disruption and extraction. Cell permeabilization was carried out by a non-mechanical method consisting of chemical treatment with ethanol, and the results were expressed as $\beta$-galactosidase activity. Experiments were conducted under different conditions of ethanol concentration, treatment time and temperature according to a central composite rotatable design (CCRD), and the collected results were then worked out by response surface methodology (RSM). Cell permeabilization was improved by an increase in ethanol concentration and simultaneous decreases in the incubation temperature and treatment time. Such an approach allowed us to identify an optimal range of the independent variables within which the $\beta$-galactosidase activity was optimized. A maximum permeabilization of $2,816 \mathrm{mmol} \mathrm{L}^{-1} \mathrm{oNP} \mathrm{min}^{-1}$ $\mathrm{g}^{-1}$ was obtained by treating cells with $75.0 \% \mathrm{v} / \mathrm{v}$ of ethanol at $20.0{ }^{\circ} \mathrm{C}$ for $15.0 \mathrm{~min}$. The proposed methodology resulted to be effective and suited for K. lactis cells permeabilization at a lab-scale and promises to be of possible interest for future applications mainly in the food industry.
\end{abstract}

Key words: yeast, cheese whey, permeabilization, ethanol, $\beta$-galactosidase.

\section{Introduction}

The genus Kluyveromyces is utilized as a source of different enzymes, among which $\beta$-galactosidase ( $\beta$-Dgalactohydrolase, EC 3.2.1.23) ( $\beta$-gal) (Barreto et al., 2000; Dagbagli and Goksungur, 2008) and inulinase (Jain et al., 2012). In particular, the species Kluyveromyces lactis can use lactose as the only carbon and energy source because of a high $\beta$-gal activity. Therefore, cheese whey, which is a source of lactose and supports growth without the need of any additional supplement (Marcel and Passos, 2011), can alternately be used as a cheap culture medium to produce $\beta$-gal.
To isolate the intracellular $\beta$-gal from $K$. lactis, cell disruption with total or partial purification is one of the key steps, making its extraction difficult and expensive ( $\mathrm{Pa}-$ nesar, 2008), and limiting its industrial applications.

Cell permeabilization is a possible alternative to cell disruption and extraction (Hettwer and Wang, 1986), because it allows maintaining the enzyme within its natural environment. Although lacking their plasma membrane semi-permeability (Galabova et al., 1996), permeabilized cells have their enzymes virtually intact. Cell permeabilization can be accomplished by physical processes, using glass beads (Numanoglu and Sungur, 2004) or a pressure cell (Faria et al., 2009), or by chemical processes such as treatment with organic solvents (Panesar et al., 2007a;

Send correspondence to A. Converti. Department of Civil, Chemical and Environmental Engineering, University of Genoa, via Opera Pia 15, 16145 Genoa, Italy. E-mail: converti@unige.it. 
Kaur et al., 2009a). To select the best permeabilization procedure it is important to establish what parameters or conditions enable to maximize the $\beta$-gal activity at a lab-scale.

One of the main problems related to chemical permeabilization is the presence of residual solvent or detergent in treated cells, which can end up polluting the final food products. As ethanol is present in many fermented dairy products for human consumption (Somkuti et al., 1998), it is undoubtedly the best solvent to this purpose. It has in fact already been used with success to permeabilize yeast cells such as those of Kluyveromyces marxianus (Panesar et al., 2007a), Saccharomyces cervisiae (Takeshige and Ouchi, 1995) and K. lactis (Genari et al., 2003).

Cell permeabilization is influenced by several operating conditions that need to be optimized. However, the traditional optimization method in which the level of one parameter is varied at a time over a certain range, while keeping the other variables constant, is generally timeconsuming, requires a large number of tests (Sen and Swaminathan, 1997), does not reflect the interaction effects among the variables and, consequently, does not depict the net effect of the various factors on the enzyme activity (Dagbagli and Goksungur, 2008). These drawbacks can be overcome by using statistical experimental factorial designs, and the experimental data of responses are usually fitted to second order polynomial functions by the response surface methodology (RSM).

In this work a central composite rotatable design combined with RSM was used to identify the optimal operating conditions to permeabilize $K$. lactis cells using ethanol as a solvent and varying its concentration, temperature and permeabilization time as the independent variables.

\section{Materials and Methods}

\section{Microorganism and maintenance}

The strain Kluyveromyces lactis CBS2359 belonging to the Collection of the Federal University of Viçosa (UFV) was used in this study. The stock culture was maintained at $-80{ }^{\circ} \mathrm{C}$ on YPD $\left(10 \mathrm{~g} \mathrm{~L}^{-1}\right.$ yeast extract; $20 \mathrm{~g} \mathrm{~L}^{-1}$ peptone and $20 \mathrm{~g} \mathrm{~L}^{-1} \mathrm{D}$-glucose) containing $40 \%$ glycerol. Before each experiment, cells were transferred and grown for $48 \mathrm{~h}$ at $30^{\circ} \mathrm{C}$ on Petri plates containing Sabouraud medium $\left(5 \mathrm{~g} \mathrm{~L}^{-1}\right.$ casein peptone; $5 \mathrm{~g} \mathrm{~L}^{-1}$ meat peptone, $20 \mathrm{~g} \mathrm{~L}^{-1} \mathrm{D}$-glucose and $15 \mathrm{~g} \mathrm{~L}^{-1}$ agar-agar).

\section{Preparation of culture medium}

Cheese whey (in powder form), kindly supplied by Conaprole (Montevideo, Uruguay), was made up of $70 \%$ $(\mathrm{w} / \mathrm{w})$ lactose, $12 \%(\mathrm{w} / \mathrm{w})$ proteins, $2 \%(\mathrm{w} / \mathrm{w})$ fats, $6 \%$ $(\mathrm{w} / \mathrm{w})$ salts and $4 \%$ moisture. To simulate lactose concentration of whey in nature, $5.75 \mathrm{~g}$ of powdered cheese whey were dissolved in $100 \mathrm{~mL}$ distilled water. The preparation was heated at $100^{\circ} \mathrm{C}$ for $10 \mathrm{~min}$ to dissolve crystallized lactose and centrifuged for $5 \mathrm{~min}$ at 2,000 rpm (Centrifuge series 600, Beckman, Fullerton, CA, USA) to remove the precipitate. The resulting whey was sterilized by autoclaving at $121{ }^{\circ} \mathrm{C}$ for $15 \mathrm{~min}$ and centrifuged again under sterile conditions, and the supernatant was used as culture medium.

\section{Growth conditions and cells preparation}

Loopfuls of cells from the plates were transferred to 500-mL Erlenmeyer flasks containing $200 \mathrm{~mL}$ of whey with approximately $50.0 \mathrm{~g} \mathrm{~L}^{-1}$ lactose. Flasks were maintained at $30{ }^{\circ} \mathrm{C}$ under agitation at $150 \mathrm{rpm}$ for $24 \mathrm{~h}$. Cells from an early culture were harvested by centrifugation $(2,000 \mathrm{rpm}, 5 \mathrm{~min})$ and washed twice with $0.1 \mathrm{M}$ potassium phosphate buffer ( $\mathrm{pH}$ 7.0). The final pellet was resuspended in $5 \mathrm{~mL}$ of the same buffer.

\section{Cell permeabilization}

Chemical permeabilization was performed in $50-\mathrm{mL}$ Erlenmeyer flasks each containing $5 \mathrm{~mL}$ of the reacting suspension consisting of ethanol according to the experimental design (Table 1), $22 \mathrm{mg}$ (dry weight) of $K$. lactis cells and $0.1 \mathrm{M}$ potassium phosphate buffer $(\mathrm{pH}$ 7.0). Flasks were incubated on an orbital shaker at $150 \mathrm{rpm}$ at a temperature and for a time depending on the above design. The supernatant was removed by 5 min-centrifugation at 2,000 rpm, and cells were washed twice with the same buffer. The final pellet was resuspended in $1 \mathrm{~mL}$ of buffer, and the enzyme activity of permeabilized cells determined as described later.

\section{Experimental design and statistical analyses}

Permeabilization tests were carried out according to a $2^{3}$-central composite rotatable design (CCRD), in which ethanol concentration $(\%, \mathrm{v} / \mathrm{v})$, treatment time $(\mathrm{min})$ and temperature $\left({ }^{\circ} \mathrm{C}\right)$ were selected as the independent variables at five levels $(-\alpha,-1,0,+1,+\alpha)$. Their ranges of val-

Table 1 - Factors and levels of the Central Composite Rotatable Design (CCRD) used for K. lactis cells permeabilization.

\begin{tabular}{llccccc}
\hline Independent variable & Factors & \multicolumn{3}{c}{ Coded and actual levels } \\
\cline { 3 - 6 } & & -1.68 & -1 & 0 & +1 & +1.68 \\
\hline$x_{1}$ & Ethanol (\%, v/v) & 7.96 & 25.0 & 50.0 & 75.0 & 92.4 \\
$x_{2}$ & Time (min) & 1.36 & 15.0 & 35.0 & 55.0 & 68.6 \\
$x_{3}$ & Temperature $\left({ }^{\circ} \mathrm{C}\right)$ & 13.2 & 20.0 & 30.0 & 40.0 & 46.8 \\
\hline
\end{tabular}


ues were selected on the basis of results of preliminary experiments (not shown). The points having for one factor an axial distance from the center of $\pm \alpha$ were selected as well. To make this design orthogonal, the axial distance $(\alpha)$ was chosen to be 1.682 , being $\alpha=2^{n / 4}$ and $n=3$ the number of variables. To estimate the experimental error as well as to check the suitability of the proposed model, the central point was repeated 5 times (all factors at level 0 ), while the remaining runs were carried out in triplicate. The coded $\left(x_{i}\right)$ and corresponding actual values $\left(X_{i}\right)$ of the independent variables are given in Table 1. So, the total number of experiments, corresponding to $2^{n}+2 \times n+$ central point runs, resulted to be 19 .

The coded levels of each factor were obtained by the equation:

$$
x_{i}=\frac{\left(X_{i}-X_{o}\right)}{\Delta X_{i}}, i=1,2,3
$$

where $X_{o}$ is the actual value of the independent variable $i$ at the central point, and $\Delta X_{i}$ the step change of $X_{i}$ corresponding to a unit variation of the dimensionless value.

According to such a design, the dependence of $\beta$-galactosidase ( $\beta$-gal) activity $(Y)$, expressed in $\mathrm{mmol} \mathrm{L}^{-1}$ oNP $\min ^{-1} \mathrm{~g}^{-1}$, on the three independent variables was described by the model:

$$
\begin{aligned}
& Y=\beta_{o}+\beta_{1} x_{1}+\beta_{2} x_{2}+\beta_{3} x_{3}+\beta_{11} x_{1}^{2}+\beta_{22} x_{2}^{2} \\
& +\beta_{33} x_{3}^{2}+\beta_{12} x_{1} x_{2}+\beta_{13} x_{1} x_{3}+\beta_{23} x_{2} x_{3}+\beta_{123} x_{1} x_{2} x_{3}
\end{aligned}
$$

where $\beta_{0}, \beta_{1}, \ldots, \beta_{123}$ are the coefficients estimates with $\beta_{0}$ having the role of a scaling constant. The first term in the equation is the intercept, the second to the fourth terms are the individual effects of each independent variable, the fifth to the seventh terms their quadratic effects, while the remaining ones do refer to the interaction effects between the independent variables two by two as well as all together.

The Student's t-test permitted us to check the statistical significance of the regression coefficients. The Fisher's test for analysis of variance (ANOVA), obtained by the PROC GLM (General Linear Models) procedure in the "SAS" software (version 9.0, SAS Institute Inc., Cary, NC, USA), was performed on experimental data to evaluate the statistical significance of the model. The "SAS" software and the "Design Expert" software (trial version 7.0.0, StatEase, Minneapolis, MN, USA) were employed for the regression analysis and graphical optimization, respectively. The statistically non-significant terms were omitted in the model.

The Response Surface Methodology (RSM) was applied to the experimental data to provide response surfaces and contour plots for different interactions of any couple of independent variables, while holding the value of the third variable constant at the $-1,0$ and +1 levels. Such three dimensional surfaces gave accurate geometrical representa- tions and provided useful information on the behavior of the system within the experimental design.

\section{Analytical methods}

Optical density of cell suspensions was determined at $600 \mathrm{~nm}\left(\mathrm{OD}_{600}\right)$ by a spectrophotometer, series 600 (Beckman, Fullerton, CA, USA), and then related to cell concentration, $X\left(\mathrm{~g}\right.$ dry weight $\left.\mathrm{L}^{-1}\right)$, through a calibration curve $\left(\mathrm{OD}_{600}=4.2194 X\right)$.

$\beta$-Gal activity of permeabilized yeast cells was determined as previously described (Fontes et al., 2001; Genari et al., 2003), with some modifications. To this purpose, after recovery of permeabilized cells by centrifugation (2,000 rpm, $5 \mathrm{~min}$ ), $0.1 \mathrm{~mL}$ of their suspension were mixed with $2.0 \mathrm{~mL}$ of $0.1 \mathrm{M}$ potassium phosphate buffer ( $\mathrm{pH} 7.2)$, $0.1 \mathrm{mM} \mathrm{MgSO}_{4}$ and $0.5 \mathrm{~mL}$ of a solution containing $4 \mathrm{mg} \mathrm{mL}{ }^{-1}$ of $o$-nitrophenyl- $\beta$-D-galactopyranoside (ONPG, Sigma, St. Louis, USA). After incubation for $7 \mathrm{~min}$ at room temperature, the reaction was interrupted by addition of $0.5 \mathrm{~mL}$ of $1.0 \mathrm{M} \mathrm{Na}_{2} \mathrm{CO}_{3}$ to $1.0 \mathrm{~mL}$ of the reaction mixture, and the absorbance was read at $420 \mathrm{~nm}$ by the above spectrophotometer. $\beta$-Gal activity was then expressed as mmol of $o$-nitrophenol (oNP) $\mathrm{L}^{-1}$ released per minute according to a standard curve. To make reference to the effect of cell concentration, the enzyme activity detected in a $0.1 \mathrm{~mL}$-sample of permeabilized cell suspension was finally expressed per gram of dry cell mass $\left(\mathrm{mmol} \mathrm{L}^{-1}\right.$ oNP $\min ^{-1} \mathrm{~g}^{-1}$ ). All activity tests were performed in triplicate and expressed as mean values.

\section{Results and Discussion}

\section{Literature survey on Kluyveromyces cells permeabilization}

As is well known, the industrial applications of $\beta$-Dgalactosidase ( $\beta$-gal) are hampered by the difficulty of recovering with satisfactory yield such an enzyme in its active form from cells as well as the cost of its purification. An interesting alternative could be the use of whole cells of bacteria and yeasts as raw material (Panesar et al., 2007a), but a major drawback is the poor permeability of their cell membrane to lactose; therefore, several attempts have been made to increase it (Panesar et al., 2006; Kaur et al., 2009a).

Among the advantages of using permeabilized cells are the easiness and rapidity of the permeabilization methods (Kaur et al., 2009b) along with the possibility of controlling the cytosolic environment by simply changing the external media (Takeshige and Ouchi, 1995), which may allow the future development of low-cost industrial operation based on this technique.

Several attempts have been made to use organic solvent as permeabilizing agent of cells of different Kluyveromyces species that are a safe source of $\beta$-gal for 
commercial preparations (Panesar et al., 2006). Decleire et al. (1987) obtained the best results of Kluyveromyces bulgaricus permeabilization using minimum solvent concentrations of $10 \% n$-butanol, $20 \%$ propanol, $30 \%$ isopropanol, tert-butanol, $40 \%$ ethanol and acetone and $70 \%$ dimethylsulphoxide. For Kluyveromyces lactis, Siso et al. (1992) determined the effectiveness of various lactose permeabilization treatments, and the best results in terms of intracellular $\beta$-gal activity were obtained with 4:96 toluene:ethanol and $70 \%(\mathrm{v} / \mathrm{v})$ ethanol under mild conditions. Good results of stabilization of permeabilized K. lactis cells were obtained by Flores (1995) with chloroform and ethanol as solvents, while ethanol-permeabilized cells of $K$. lactis (Genari et al., 2003) and Kluyveromyces marxianus (Panesar et al., 2007b) were successfully used in immobilized cell systems for hydrolysis of lactose in milk. As far as other possible transformations are concerned, ethanol-permeabilized cells of K. lactis and K. marxianus CCT 7082 were also used with success in lactose and fructose bioconversion to lactulose (Lee et al., 2004) and in the production of galacto-oligosaccharides (Manera et al., 2010), respectively.

In their study of $K$. marxianus cells permeabilization with different solvents (benzene, $n$-butanol, $n$-propanol, Triton X-100, acetone, ethanol, isopropanol and toluene), Panesar et al. (2007a) separately investigated the effects of solvent concentration, temperature and treatment time, and found, under optimal treatment conditions $(50 \% \mathrm{v} / \mathrm{v}$ ethanol, $25{ }^{\circ} \mathrm{C}$ for $15 \mathrm{~min}$ ) a maximum permeabilization yield of 1,540 $\mu \mathrm{mol}$ oNP $\min ^{-1} \mathrm{~g}^{-1}$. However, variation of only one condition at a time did not allow taking into account the possible influence of variable interactions on the enzyme activity.

Thus, the use of suitable experimental design combined with Response Surface Methodology (RSM) proved to be an interesting tool to reduce the number of tests and simplify the optimization of yeast cells permeabilization. Following this approach, Kaur et al. (2009b) applied RSM to optimize the concentration of cetyltrimethylammonium $(0.06 \%, \mathrm{w} / \mathrm{v})$, temperature $\left(28^{\circ} \mathrm{C}\right)$ and treatment time $(14$ min), thus obtaining a maximum permeabilization of $K$. marxianus var. lactis cells expressed as $\beta$-gal activity of $1,334 \mu \mathrm{mol}$ oNP $\min ^{-1} \mathrm{~g}^{-1}$. In a similar approach, but using ethanol as a solvent, Panesar (2008) extrapolated a maximum activity of permeabilized $K$. marxianus cells of 1,573 $\mu \mathrm{mol}$ oNP $\min ^{-1} \mathrm{~g}^{-1}$.

In view of future commercial applications, the yeast $K$. lactis deserves special attention, as it is considered by the United States Food and Drug Administration as a safe organism for the use and production of $\beta$-gal aimed at the food industry (Bonekamp and Oosterom, 1994), and ethanol proved, according to the above-mentioned literature, to be the most effective agent to permeabilize yeast cells. Taking into account that this chemical is often present in fermented dairy products, its use could contribute to reduce the risk of toxicity associated with others chemicals presently used to permeabilize cells. Based on this background, RSM was applied in this work to optimize the conditions of $K$. lactis cells permeabilization with ethanol, evaluated in terms of their $\beta$-gal activity, whose main results are summarized in the following.

\section{Statistical model and response surfaces}

To find out the effectiveness of ethanol as a permeabilizing agent, we searched the optimal values of the independent variables (ethanol concentration, treatment time and temperature) able to ensure maximum $\beta$-gal activity of K. lactis cells.

The average results of permeabilization tests performed according to the Central Composite Rotatable Design (CCRD) described in the Materials and Methods section are summarized in Table 2. It should be noticed that $\beta$-gal activity reached a maximum $\left(3,197 \mathrm{mmol} \mathrm{L}^{-1}\right.$ oNP $\min ^{-1} \mathrm{~g}^{-1}=8,311 \mu \mathrm{mol}$ oNP $\min ^{-1} \mathrm{~g}^{-1}$ ) with $75.0 \% \mathrm{v} / \mathrm{v}$ ethanol at $20.0^{\circ} \mathrm{C}$ after 15.0 min of treatment (run 5), while it dramatically fell (to $6.00 \mathrm{mmol} \mathrm{L}^{-1}$ oNP $\min ^{-1}$ $\mathrm{g}^{-1}=15.62 \mu \mathrm{mol}$ oNP $\min ^{-1} \mathrm{~g}^{-1}$ ) when temperature was raised to $40.0{ }^{\circ} \mathrm{C}$ keeping constant the other conditions (run 6), and even disappeared protracting this last treatment for $55.0 \mathrm{~min}$ (run 8).

After elimination of the statistically insignificant terms $(p>0.05)$, application of the multiple regression analysis to these experimental data led to the following model describing the simultaneous influence of the three independent variables on $K$. lactis cells permeabilization expressed as $\beta$-gal activity:

$$
\begin{aligned}
& Y=58.241 x_{1}-308.969 x_{2}-606.676 x_{3}+ \\
& 184.391 x_{1}^{2}+288.036 x_{2}^{2}+328.551 x_{3}^{2}- \\
& 207.686 x_{1} x_{2}-282.105 x_{1} x_{3}+180.432 x_{2} x_{3}+ \\
& 370.922 x_{1} x_{2} x_{3}
\end{aligned}
$$

Taken as a whole, the results of analysis of variance (ANOVA) applied to these results show that the above model was actually significant for the system under consideration (Table 3). A $F$-value of 56.69 and a p-value $<0.0001$ do in fact mean that the regression was statistically significant $\left(\mathrm{F}_{\text {calculated }}>\mathrm{F}_{\text {table }}\right.$ and $\mathrm{p}$-value $\left.<0.05\right)$. Moreover, the high value of the determination coefficient $\left(r^{2}=0.9072\right)$ points out that only $9.28 \%$ of the total response variations were not explained by the model, thus proving its validity despite a significant lack of fit.

Table 4 lists the values of all the coefficients (linear, quadratic and interaction ones) of the three independent variables in the polynomial model (Eq. (3)), whose statistical significance was evaluated by the Student's $t$-test and the $\mathrm{p}$-value. One can see that, apart from the intercept $\left(\beta_{0}\right)$ and the linear contribution of ethanol concentration $\left(x_{l}\right)$, all 
Table 2 - Experimental design matrix employed for $K$. lactis cells permeabilization and average $\beta$-gal activity of permeabilized cells.

\begin{tabular}{|c|c|c|c|c|}
\hline \multirow[t]{2}{*}{ Run } & \multicolumn{3}{|c|}{ Independent variable } & \multirow{2}{*}{$\begin{array}{c}\text { Response } \\
\beta \text {-gal activity }\left(\mathrm{mmol} \mathrm{L}^{-1} \text { oNP } \min ^{-1} \mathrm{~g}^{-1}\right)\end{array}$} \\
\hline & $x_{1}$ & $x_{2}$ & $x_{3}$ & \\
\hline 1 & -1 & -1 & -1 & 1,365 \\
\hline 2 & -1 & -1 & +1 & 786.2 \\
\hline 3 & -1 & +1 & -1 & 1,468 \\
\hline 4 & -1 & +1 & +1 & 127.2 \\
\hline 5 & +1 & -1 & -1 & 3,197 \\
\hline 6 & +1 & -1 & +1 & 6.00 \\
\hline 7 & +1 & +1 & -1 & 985.3 \\
\hline 8 & +1 & +1 & +1 & 0.00 \\
\hline 9 & -1.68 & 0 & 0 & 146.9 \\
\hline 10 & +1.68 & 0 & 0 & 357.0 \\
\hline 11 & 0 & -1.68 & 0 & 975.2 \\
\hline 12 & 0 & +1.68 & 0 & 115.4 \\
\hline 13 & 0 & 0 & -1.68 & 1,311 \\
\hline 14 & 0 & 0 & +1.68 & 8.48 \\
\hline 15 & 0 & 0 & 0 & 187.1 \\
\hline 16 & 0 & 0 & 0 & 163.1 \\
\hline 17 & 0 & 0 & 0 & 183.5 \\
\hline 18 & 0 & 0 & 0 & 135.1 \\
\hline 19 & 0 & 0 & 0 & 208.2 \\
\hline
\end{tabular}

Table 3 - Results of Analysis of Variance (ANOVA) applied to the results of $K$. lactis permeabilization tests performed according to the CCRD.

\begin{tabular}{lccccc}
\hline Source & SS & DF & MS & $F$-value & p-value \\
\hline Model & $5.2361 \times 10^{7}$ & 10 & $5.2361 \times 10^{6}$ & 56.69 & $<0.0001$ \\
Residual & $4.3410 \times 10^{6}$ & 47 & $9.2362 \times 10^{4}$ & & $<0.0001$ \\
Lack of fit & $4.1214 \times 10^{6}$ & 5 & $8.2428 \times 10^{5}$ & $5.229 \times 10^{3}$ & \\
Pure error & $2.1963 \times 10^{5}$ & 42 & & \\
Total & $5.6702 \times 10^{7}$ & 57 & & \\
\hline
\end{tabular}

$\mathrm{SS}=$ sum of squares, $\mathrm{DF}=$ degrees of freedom, $\mathrm{MS}=$ mean square.

Table 4 - Estimated coefficients of the regression analysis performed on the results of $K$. lactis permeabilization tests

\begin{tabular}{lcccc}
\hline Term & Coefficients & Standard error & $t$-value & p-value \\
\hline$x_{1}$ & 58.241 & 47.491 & 1.23 & 0.2262 \\
$x_{2}$ & -308.969 & 47.491 & -6.51 & $<0.0001$ \\
$x_{3}$ & -606.676 & 47.491 & -12.77 & $<0.0001$ \\
$x_{1}{ }^{2}$ & 184.391 & 39.237 & 4.70 & $<0.0001$ \\
$x_{2}{ }^{2}$ & 288.036 & 39.237 & 7.34 & $<0.0001$ \\
$x_{3}{ }^{2}$ & 328.551 & 39.237 & 8.37 & $<0.0001$ \\
$x_{1} x_{2}$ & -207.686 & 62.053 & -3.35 & 0.0016 \\
$x_{1} x_{3}$ & -282.105 & 62.053 & -4.55 & $<0.0001$ \\
$x_{2} x_{3}$ & 180.432 & 62.053 & 2.91 & 0.0055 \\
$x_{1} x_{2} x_{3}$ & 370.922 & 62.053 & 5.98 & $<0.0001$ \\
\hline
\end{tabular}

the terms were statistically significant ( $p$-value $<0.05$ ). Although not statistically significant ( $\mathrm{p}$-value $>0.05$ ), the term $x_{1}$ was maintained in the model for hierarchy, since the quadratic contribution of ethanol concentration and its interactions were significant.

In particular, the permeabilization time $\left(x_{2}\right)$ and the incubation temperature $\left(x_{3}\right)$ exerted negative individual effects on $\beta$-gal activity of permeabilized cells ( $p$-value $<0.05)$, their linear correlation coefficients having negative sign ( $\beta_{2}=-308.969, \beta_{3}=-606.676$, respectively). The $t$-test also evidenced that the response was influenced by the positive quadratic contributions of all the three independent variables $\left(\beta_{11}=+184.391, \beta_{22}=+288.036\right.$, $\left.\beta_{33}=+328.551\right)$. As shown by the very low $p$-values, all the interactions between ethanol concentration and time $\left(x_{1} x_{2}\right)$, ethanol concentration and temperature $\left(x_{1} x_{3}\right)$, time and tem- 
perature $\left(x_{2} x_{3}\right)$ and ethanol concentration, time and temperature $\left(x_{1} x_{2} x_{3}\right)$ were significant ( $\mathrm{p}$-value $\left.<0.05\right)$. However, contrary to the other binary interactions, the $x_{1} x_{2}$ and $x_{1} x_{3}$ ones were negative $\left(\beta_{12}=-207.686, \beta_{13}=-282.105\right)$, which means that any increase in ethanol concentration in any combination with the other variables led to a statisticallysignificant decrease in the enzyme activity of permeabilized cells.

Among all the contributions investigated, the ternary interaction among ethanol concentration, time and temperature $\left(x_{1} x_{2} x_{3}\right)$ along with the linear contribution of temperature $\left(x_{3}\right)$ had the highest positive $\left(\beta_{123}=370.922\right)$ and negative $\left(\beta_{3}=-606.676\right)$ impacts on cell permeabilization, respectively.

To effectively visualize the combined effects of time and temperature on $\beta$-gal activity of $K$. lactis permeabilized cells, ethanol concentration was kept constant at the selected three levels $(-1,0$ and +1$)$, and the corresponding contours plots described by the model are illustrated in Figures 1, 2 and 3, respectively. It can be seen in Figure 1 that, with $25.0 \%(\mathrm{v} / \mathrm{v})$ ethanol, the lower the temperature the higher the $\beta$-gal activity, irrespectively of the treatment time, which suggests that, under these mild conditions, ethanol was likely to be insufficient to perform an effective permeabilization. On the other hand, at higher solvent concentrations (50.0 and $75.0 \%$, v/v) (Figures 2 and 3, respectively), whereas the temperature exerted the same effect as that depicted in Figure 1, the $\beta$-gal activity was shown to increase with shortening the time. It is likely that, operating under severe conditions (high temperature, high ethanol concentration, long treatment time), ethanol could have partially inactivated the enzyme or even lysed the cells. As

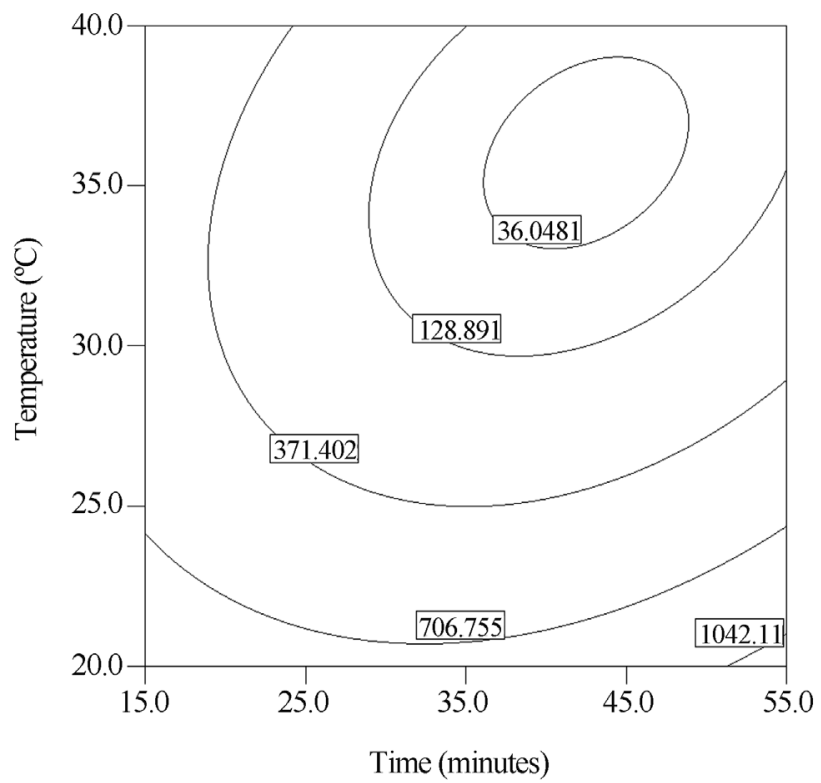

Figure 1 - Contour plots of $\beta$-galactosidase activity of $K$. lactis cells permeabilized with $25.0 \%(\mathrm{v} / \mathrm{v})$ ethanol. a result, comparing the three contour plots, we can observe that the highest $\beta$-gal activities were obtained at the highest ethanol concentration, the lowest temperature and the shortest permeabilization time.

The results obtained in this study only partly agree with those reported in the literature, which demonstrated that an increase in ethanol concentration improved the permeabilization process up to a maximum threshold, and then decreased above this value. In particular, Panesar et al. (2007b), working at room temperature for $15 \mathrm{~min}$, observed an increase in the permeabilization of $K$. marxianus NCIM 3465 cells up to $1,540 \mu \mathrm{mol}$ oNP $\min ^{-1} \mathrm{~g}^{-1}$ with progres-

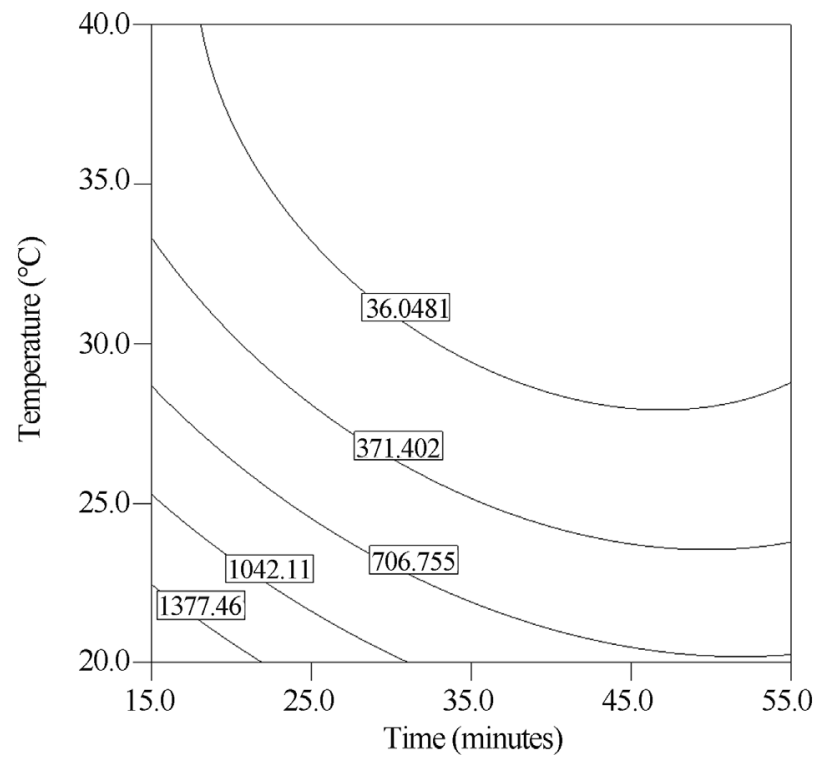

Figure 2 - Contour plots of $\beta$-galactosidase activity of $K$. lactis cells permeabilized with $55.0 \%(\mathrm{v} / \mathrm{v})$ ethanol.

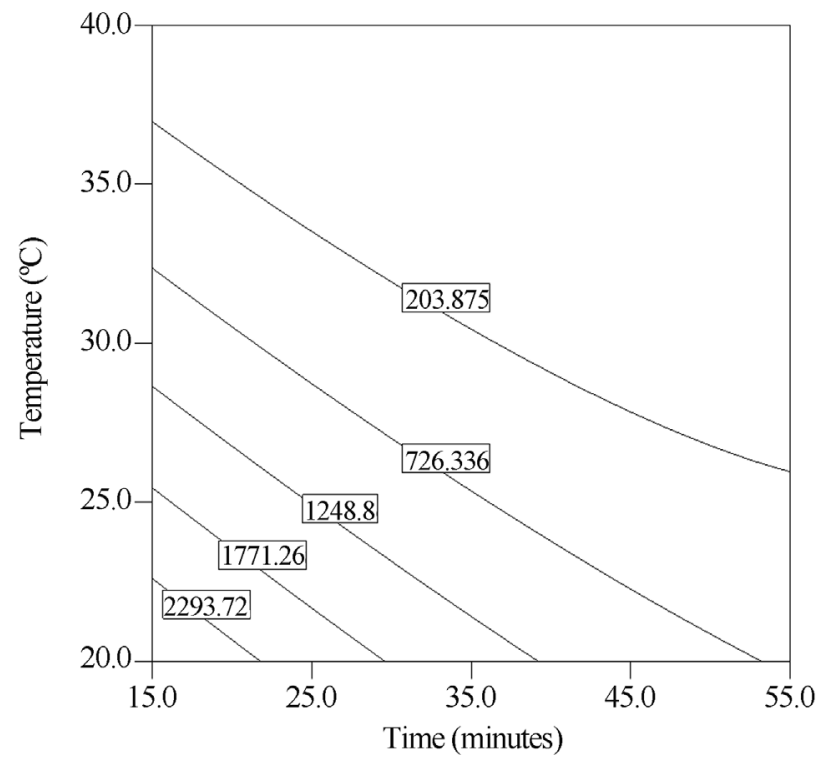

Figure 3 - Contour plots of $\beta$-galactosidase activity of $K$. lactis cells permeabilized with $75.0 \%(\mathrm{v} / \mathrm{v})$ ethanol. 
Table 5 - Optimum conditions of $K$. lactis cells permeabilization predicted by overlaying the response surface plots.

\begin{tabular}{lcccc}
\hline Number & Ethanol $(\%, \mathrm{v} / \mathrm{v})$ & Time $(\mathrm{min})$ & Temperature $\left({ }^{\circ} \mathrm{C}\right)$ & $\beta$-gal activity $\left(\mathrm{mmol} \mathrm{L}^{-1} \mathrm{oNP} \mathrm{min}^{-1} \mathrm{~g}^{-1}\right)$ \\
\hline 1 & 75.0 & 15.0 & 20.0 & 2,816 \\
2 & 75.0 & 15.0 & 20.1 & 2,795 \\
3 & 75.0 & 15.4 & 20.0 & 2,783 \\
\hline
\end{tabular}

sively raising ethanol concentration from 20 to $50 \%(\mathrm{v} / \mathrm{v})$, and a subsequent decrease. In similar work performed for 20 min with the same microbial system, but varying temperature $\left(20-30{ }^{\circ} \mathrm{C}\right)$ and ethanol concentration $(45-55 \%$, $\mathrm{v} / \mathrm{v}$ ) according to a CCRD, Panesar (2008) found an optimum permeabilization of $1,573 \mu \mathrm{mol}$ oNP $\mathrm{min}^{-1} \mathrm{~g}^{-1}$ operating at $25{ }^{\circ} \mathrm{C}$ with $50 \%(\mathrm{v} / \mathrm{v})$ ethanol, and ascribed the performance decrease at higher ethanol levels to the leakage of enzyme from cells or even cells lysis. So, one can infer that the lower temperature used in the present work in some experiments $\left(20.0{ }^{\circ} \mathrm{C}\right)$ could have favored the permeabilization with higher ethanol concentration $(75.0 \%$, $\mathrm{v} / \mathrm{v}$ ) or that the different strain used could have exhibited a greater resistance to high solvent levels.

\section{Optimization of the permeabilization process}

A numerical optimization was carried out in the final part of this study to identify the overall optimal conditions for $K$. lactis cells permeabilization. To this purpose, the three independent variables were numerically varied according to the proposed factorial design, by conferring them the same importance or weight by means of the "Design expert" software and imposing, as a constraint, the obtaining of maximum $\beta$-gal activity as high as possible.

The optimal working conditions extrapolated by this approach are presented in Table 5. A maximum theoretical $\beta$-gal activity of $2,816 \mathrm{mmol} \mathrm{L}^{-1}$ oNP $\min ^{-1} \mathrm{~g}^{-1}(7,322 \mu \mathrm{mol}$ oNP $\min ^{-1} \mathrm{~g}^{-1}$ ) was predicted for $75.0 \% \mathrm{v} / \mathrm{v}$ ethanol, $20.0^{\circ} \mathrm{C}$ and $15.0 \mathrm{~min}$, i.e. for the conditions of the run 5 (Table 2). Since the experimental $\beta$-gal activity obtained in this run $\left(3,197 \mathrm{mmol} \mathrm{L}^{-1}\right.$ oNP $\min ^{-1} \mathrm{~g}^{-1}=8,311 \mu \mathrm{mol}$ oNP $\left.\min ^{-1} \mathrm{~g}^{-1}\right)$ was only $13.5 \%$ higher than the above predicted value, this result confirms the validity of the optimization approach. Finally, the effectiveness of the permeabilization process under the optimal conditions of this study is demonstrated by the fact that the above maximum activity is more than 5-fold that predicted by Panesar (2008) for K. marxianus cells $\left(1,573 \mu \mathrm{mol}\right.$ oNP $\left.\min ^{-1} \mathrm{~g}^{-1}\right)$ corresponding to an ethanol concentration of $49.6 \% \mathrm{v} / \mathrm{v}$, a temperature of $23^{\circ} \mathrm{C}$ and a treatment time of $18 \mathrm{~min}$.

\section{Conclusions}

The method of cell permeabilization developed in this work is a promising one to reduce the cost of $\beta$-galactosidase ( $\beta$-gal) to be used as a biocatalyst in the food industry. It promises to overcome the need of complex and expensive purification steps as well as to ensure, at the same time, high enzyme activity of the resulting cells. Analysis of results expressed as $\beta$-gal activity of permeabilized Kluyveromyces lactis CBS 2359 cells by Response Surface Methodology allowed identifying the experimental conditions able to optimize the process. Under optimized conditions, $\beta$-gal activity of $K$. lactis permeabilized cells resulted to be appreciably higher than those reported in the literature, thereby demonstrating the effectiveness of the proposed method. Ethanol proved to be an effective agent to permeabilize cells of this yeast. Taking into account that this chemical is often present in fermented dairy products, its use could contribute to reduce the risk of toxicity associated with others chemical treatments presently employed for cell permeabilization. Keeping these considerations in mind, the hydrolysis of lactose contained in whey could successfully be performed at an industrial level by cells of $K$. lactis preliminarily permeabilized with ethanol as a cheap alternative to the use of purified enzymes.

\section{Acknowledgments}

The authors wish to thank the Brazilian agencies, Conselho Nacional de Desenvolvimento Científico e Tecnológico $(\mathrm{CNPq})$ and Fundação de Amparo à Pesquisa do Estado de Minas Gerais (FAPEMIG), for the financial support.

\section{References}

Barreto ES, Silva DO, Passos FML (2000) A practical method for screening for $\beta$-galactosidase secreting microbial colonies. Braz J Microbiol 31:37-38.

Bonekamp FJ, Oosterom J (1994) On the safety of Kluyveromyces lactis - A review. Appl Microbiol Biotechnol 41:1-3.

Dagbagli S, Goksungur Y. (2008) Optimization of $\beta$-galactosidase production using Kluyveromyces lactis NRRL Y-8279 by response surface methodology. Electronic J Biotechnol 11:11-12.

Decleire M, De Cat W, Van Huynh N. (1987) Comparison of various permeabilization treatments on Kluyveromyces by determining in situ $\beta$-galactosidase activity. Enzyme Microb Technol 9:300-302.

Faria JT, Sampaio FC, Converti A, Passos FML, Minim LA (2009) Use of response surface methodology to evaluate the extraction of Debaryomyces hansenii xylose reductase by aqueous two-phase system. J Chrom B 877:3031-3037.

Flores MV (1995) Stabilization of a cell biocatalyst with $\beta$-galactosidase activity by glutaraldehyde treatment. J Chem Technol Biotechnol 64:353-360. 
Fontes EAF, Passos FML, Passos FJV (2001) A mechanistical mathematical model to predict lactose hydrolysis by $\beta$-galactosidase in a permeabilized cell mass of Kluyveromyces lactis: validity and sensitivity analysis. Process Biochem 37:267-274.

Galabova D, Tuleva B, Spasova D (1996) Permeabilization of Yarrowia lipolytica cells by Triton X-100. Enzyme Microb Technol 18:8-22.

Genari NA, Passos FML, Passos FJV (2003) Configuration of a bioreactor for milk lactose hydrolysis. J Dairy Sci 86:27832789.

Hettwer DJ, Wang HY (1986) Protein release from chemically permeabilized Escherichia coli. In: Asenjo JA, Hong J. (eds) Separation, Recovery and Purification in Biotechnology. Americam Chemical Society ACS Symposium Series 314, Washington DC, USA, pp 2-8.

Jain SC, Jain PC, Kango N (2012) Production of inulinase from Kluyveromyces marxianus using Dahlia tuber extract. Braz J Microbiol 43:62-69.

Kaur G, Panesar PS, Bera MB, Kumar EH (2009a) Hydrolysis of whey lactose using CTAB-permeabilized yeast cells. Bioprocess Biosyst Eng 32:63-67.

Kaur G, Panesar PS, Bera MB, Singh B (2009b) Optimization of permeabilization process for lactose hydrolysis in whey using response surface methodology. J Food Process Eng 32:355-368.

Lee Y-J, Kim D-K, Oh D-K (2004) Lactulose production by $\beta$-galactosidase in permeabilized cells of Kluyveromyces lactis. Appl Microbiol Biotechnol 64:787-793.

Manera AP, Costa FAA, Rodrigues MI, Kalil SJ, Filho FM (2010) Galacto-oligosaccharides production using permeabilized cells of Kluyveromyces marxianus. Int J Food Eng 6:e4.

Marcel JRP, Passos FML (2011) Solvent extraction of $\beta$-galactosidase from Kluyveromyces lactis yields a stable highly active enzyme preparation. J Food Biochem 35:323-336.
Numanoglu Y, Sungur S (2004) Galactosidase from Kluyveromyces lactis cell disruption and enzyme immobilization using a cellulose-gelatin carrier system. Process Biochem 39:703-709.

Panesar PS, Panesar R, Singh RS, Bera MB (2007a) Permeabilization of yeast cells with organic solvent for $\beta$-galactosidase activity. Res J Microbiol 2:34-41.

Panesar R, Panesar PS, Singh RS, Kennedy JF, Bera MB (2007b) Production of lactose-hydrolyzed milk using ethanol permeabilized yeast cells. Food Chem 101:786-790.

Panesar SP (2008) Application of response surface methodology in the permeabilization of yeast cells for lactose hydrolysis. Biochem Eng J 39:91-96.

Panesar SP, Panesar R, Singh RS, Kennedy JF, Kumar H (2006) Review: Microbial production, immobilization and applications of $\beta$-D-galactosidase. J Chem Technol Biotechnol 81:530-543.

Sen R, Swaminathan T (1997) Application of response-surface methodology to evaluate the optimum environmental conditions for the enhanced production surfactin. Appl Microbiol Biotechnol 47:358-363.

Siso MIG, Cerdán E, Picos MAF, Ramil E, Belmonte ER, Torres AR (1992) Permeabilization of Kluyveromyces lactis cells for milk whey saccharification: A comparison of different treatments. Biotechnol Techniques 6:289-292.

Somkuti GA, Dominiecki ME, Steinberg D.H (1998) Permeabilization of Streptococcus thermophilus and Lactobacillus delbrueckii subsp. bulgaricus with ethanol. Curr Microbiol 36:202-206.

Takeshige K, Ouchi K (1995) Reconstruction of ethanol fermentation in permeabilized cells of the yeast Saccharomyces cerevisiae. J Ferment Bioeng 79:11-16.

All the content of the journal, except where otherwise noted, is licensed under a Creative Commons License CC BY-NC. 